\title{
KEMAMPUAN BERPIKIR KRITIS PESERTA DIDIK MELALUI PENERAPAN MODEL PEMBELAJARAN SEARCH, FIND, AND CONSTRUCT TOGETHER (SFCT) PADA MATERI MATRIKS KELAS XI SMA NEGERI 2 MALANG
}

\author{
Tutut Noviyanti ${ }^{1}$ \\ ${ }^{1}$ Program Studi Pendidikan Matematika FKIP Universitas Islam Malang \\ Email: ${ }^{\text {tututnoviy@gmail.com, }}$
}

\begin{abstract}
Abstrak
Tujuan penelitian ini adalah untuk mengetahui apakah terdapat perbedaan kemampuan berpikir kritis dan untuk mendeskripsikan kemampuan berpikir kritis antara peserta didik yang diajar menggunakan model pembelajaran Search, Find, And Construct Together (SFCT) dan model pembelajaran konvensional. Metode penelitian yang digunakan adalah metode penelitian kombinasi dengan desain sequential explanatory. Sampel data kuantitatif adalah peserta didik kelas XI MIPA 1 dan XI MIPA 2, penelitian kuantitatif ini diperoleh dengan tes kemampuan berpikir kritis peserta didik. Analisis data yang digunakan adalah uji t dengan uji prasyarat yaitu uji normalitas dan uji homogenitas. Subjek penelitian kualitatif sebanyak 9 peserta didik. Sembilan peserta didik tersebut dipilih berdasarakan kemampuan berpikir kritis tinggi, sedang, dan rendah. Sedangkan pengumpulan data kualitatif dilakukan dengan observasi, wawancara, dan catatan lapangan. Hasil penelitian menunjukkan bahwa (1) Berdasarkan hasil analisis data kuantitatif dengan uji hipotesis menggunakan software SPSS 20 diperoleh nilai Sig 2-tailed = 0,009. Karena nilai $\mathrm{Sig}=0,009<0,025$ maka $\mathrm{H}_{0}$ ditolak. Hal ini berarti dapat disimpulkan bahwa terdapat perbedaan yang signifikan kemampuan berpikir kritis antara peserta didik yang diajar dengan model pembelajaran SFCT dan peserta didik yang diajar menggunakan model konvensional. (2) Berdasarkan analisis data kualitatif yang diperoleh dari wawancara dapat disimpulkan bahwa peserta didik senang diajar menggunakan model SFCT dan sebanyak $80,56 \%$ peserta didik memenuhi empat indikator berpikir kritis, sedangkan peserta didik tidak senang diajar menggunakan model konvensional dan hanya $63,86 \%$ peserta didik yang memenuhi empat indikator berpikir kritis.
\end{abstract}

Kata Kunci: pembelajaran matematika, model pembelajaran SFCT, kemampuan berpikir kritis

\begin{abstract}
The purpose of this study was to determine whether there were differences in critical thinking skills and to describe critical thinking skills among students taught using the Search learning model, Find, And Construct Together (SFCT) and conventional learning models. The research method used is a combination research method with sequential explanatory design. Quantitative data samples were students of class XI MIPA 1 and XI MIPA 2, this quantitative research was obtained by testing students' critical thinking skills. Analysis of the data used is the $\mathrm{t}$ test with the prerequisite test, namely the normality test and homogeneity test. Qualitative research subjects were 9 students. The nine students were selected based on high, medium and low critical thinking skills. While the collection of qualitative data is done by observation, interviews, and field notes. The results showed that (1) Based on the results of quantitative data analysis with hypothesis testing using SPSS 20 software, the Sig 2-tailed value was obtained $=0.009$. Because the Sig value $=0.009<0.025$ then $\mathrm{H}_{0}$ is rejected. This means that it can be concluded that there are significant differences in critical thinking skills between students who are taught by the SFCT learning model and students who were taught using conventional models. (2) Based on qualitative data analysis obtained from interviews, it can be concluded that students like to be taught using the SFCT model and as many as $80.56 \%$ of students fulfill four indicators of critical thinking, while students are not happy to be taught using conventional models and only $63.86 \%$ students who fulfill the four indicators of critical thinking.
\end{abstract}




\section{PENDAHULUAN}

Undang-undang Nomor 20 Tahun 2003 tentang Sistem Pendidikan Nasional menyebutkan bahwa pendidikan nasional berfungsi mengembangkan kemampuan dan membentuk watak serta peradaban bangsa yang bermartabat dalam rangka mencerdaskan kehidupan bangsa. Pendidikan bertujuan untuk mengembangkan potensi peserta didik agar menjadi manusia yang beriman bertakwa kepada Tuhan Yang Maha Esa, berakhlak mulia, sehat, berilmu, cakap, kreatif, mandiri, dan menjadi warga negara yang demokratis serta bertanggung jawab.

Berdasarkan Undang-undang SISDIKNAS Nomor 20 Tahun 2003, pendidikan adalah sebagai usaha sadar dan terencana untuk mewujudkan suasana belajar dan proses pembelajaran sedemikian rupa supaya peserta didik dapat mengembangkan potensi dirinya secara aktif supaya memiliki pengendalian diri, kecerdasan, ketrampilan dalam bermasyarakat, kekuatan spiritual keagamaan, kepribadian dan akhlak. Sejalan dengan undang-undang SISDIKNAS tersebut, kurikulum 2013 yang telah ditetapkan menitikberatkan pada kegiatan pembelajaran yang melibatkan peran aktif peserta didik yaitu dengan menggunakan pendekatan saintifik. Kurikulum 2013 akan membuat peserta didik tidak hanya belajar dengan menghafal rumus yang sudah tertulis dalam buku, tetapi juga menyelesaikan masalah yang ada di masyarakat secara kritis dan analitis. Menurut Cottrell (dalam As'ari, 2016: 2) hampir setiap orang dalam kehidupan sehari-hari selalu melibatkan kegiatan berpikir kritis. Kegiatan berpikir kritis itu antara lain adalah kegiatan ketika seseorang : (1) harus mengambil keputusan apakah harus mempercayai apa yang dilihat dan didengar,

(2) mengambil langkah untuk menyelidiki kebenaran sesuatu, (3) mengemukakan argumen terhadap orang yang tidak sepaham.

Matematika merupakan suatu alat untuk mengembangkan cara berpikir, karena itu matematika sangat diperlukan baik untuk kehidupan sehari-hari maupun dalam menghadapi kemajuan IPTEK. Oleh karena itu, matematika perlu dibekalkan kepada setiap peserta didik sejak SD bahkan TK (Hudojo, 2005: 35). Sedangkan menurut Uno (2008: 129) matematika adalah suatu bidang ilmu yang merupakan alat pikir, berkomunikasi, alat untuk memecahkan berbagai persoalan praktis, yang unsurnya meliputi logika, intuisi, analisis, konstruksi, generalitas dan individualitas, serta mempunyai beberapa cabang antara lain aritmatika, aljabar, geometri, dan analisis.

Pembelajaran matematika harus memberikan kesempatan kepada peserta didik untuk berusaha mngkonstruksikan pengetahuan dan pengalaman tentang matematika. Heruman (2012:4) menyatakan bahwa pembelajaran matematika harus terdapat keterkaitan antara pengalaman belajar peserta didik sebelumnya dengan konsep yang akan diajarkan. Dalam matematika setiap konsep berkaitan dengan konsep yang lain, dan suatu konsep menjadi prasyarat bagi konsep lain. Oleh karena itu peserta didik harus lebih banyak diberi kesempatan untuk melakukan keterkaitan antar konsep tersebut.

Pembelajaran matematika perlu ditangani secara khusus, sehingga diharapkan dapat menciptakan generasi penerus bangsa yang dapat menguasai matematika dengan baik dan dapat mengimplementasikan matematika dalam kehidupan sehari-hari. Kurikulum Nasional Indonesia tahun 2013 Berdasarkan Permendikbud Nomor 54 tahun 2013 tentang Standar Kompetensi Lulusan secara garis besar mengharapkan peserta didik aktif dalam mencari dan menemukan pemahaman baru, kritis dalam mengkonstruksi ilmu-ilmu yang telah mereka miliki dengan ilmu baru, kreatif dalam mengembangkan apa yang telah peserta didik miliki untuk menghasilkan sesuatu yang baru. Namun selama proses pembelajaran yang terjadi di sekolah memperlihatkan bahwa guru lebih aktif dalam pembelajaran daripada aktivitas peserta didik yang secara aktif dalam pembelajaran seperti peserta didik bertanya dan mencari pengetahuan dengan kemampuan sendiri.

Pada dasarnya objek pembelajaran matematika adalah abstrak, oleh karena itu pembelajaran matematika disekolah tidak dapat terlepas dari sifat-sifat matematika yang abstrak dan sifat perkembangan intelektual peserta didik (Suherman, dalam Nurhalifah 2014: 17). Selanjutnya Suherman mengemukakan kararkteristik pembelajaran matematika disekolah antara lain: (1) 
Pembelajaran matematika berjenjang (bertahap): materi pembelajaran diajarkan secara berjenjang atau bertahap, yaitu dari abstrak, hal yang sederhana ke kompleks, atau konsep mudah ke konsep yang lebih sukar; (2) Pembelajaran matematika mengikuti metode spiral: setiap mempelajari konsep baru perlu memperhatikan konsep atau bahan yang telah dipelajari sebelumnya. Bahan yang baru selalu dikaitkan dengan bahan yang telah dipelajari. Pengulangan konsep dalam bahan ajar dengan cara memperluas dan memperdalam adalah perlu dalam pembelajaran matematika (spiral melebar dan menaik); (3) Pembelajaran matematika menekankan pola pikir deduktif: matematika adalah deduktif, matematika tersusun secara deduktif aksiomatik. Namun demikian, harus dapat dipilih model pembelajaran yang cocok dengan kondisi peserta didik; (4) Pembelajaran matematika menganut kebenaran konsistensi: kebenaran-kebenaran dalam matematika pada dasarnya merupakan kebenaran konsistensi, tidak bertentangan antara kebenaran suatu konsep dengan yang lainnya. Suatu pernyataan dianggap benar jika didasarkan atas pernyataan-pernyataan sebelumnya yang telah diterima kebenarannya.

Gerhand (dalam Suwarma, 2009: 11), mendefinisikan berpikir kritis sebagai proses kompleks yang melibatkan penerimaan dan penguasaan data, analisis data, evaluasi data, dan mempertimbangkan aspek kualitatif dan kuantitatif, serta membuat seleksi atau membuat keputusan bersadarkan hasil evaluasi. Sedangkan Ennis (dalam As'ari 2016: 2-3) menyatakan berpikir kritis sebagai berpikir yang logis dan reflektif yang difokuskan kepada pengambilan keputusan apa yang harus dipercaya atau apa yang harus dilakukan. Dari beberapa penjelasan tersebut yang dimaksudkan kemampuan berpikir kritis dalam penelitian ini adalah suatu kemampuan berpikir yang logis, reflektif, dan sistematis yang memungkinkan peserta didik untuk mengambil suatu keputusan yang tepat. Pada penelitian ini indikator berpikir kritis yang digunakan antara lain: (a) Elementary clarification (memberikan penjelasan sederhana), (b) Strategies and tactics (strategi dan taktik), (c) Advanced clerivication (membuat penjelasan lebih lanjut), (d) Inference (menyimpulkan).

Berdasarkan hasil wawancara dengan salah seorang guru mata pelajaran matematika SMA Negeri 2 Malang yaitu Ibu Farida Agustiningsih, S.Si pada tanggal 13 Maret 2017, diperoleh informasi bahwa pembelajaran yang dilakukan sudah menggunakan pendekatan pembelajaran saintifik, guru juga terkadang menggunakan model pembelajaran PBL (Problem Based Learning), namun model PBL tersebut tidak dapat diterapkan ke semua kelas karena tidak semua peserta didik mampu. Selain itu proses pembelajaran belum menekankan pada kemampuan berpikir kritis peserta didik secara khusus. Dari hasil pre-test kemampuan berpikir kritis yang telah dilakukan sebelum perlakuan pada tanggal 14 Maret 2017 terlihat bahwa, peserta didik kelas XI MIPA 1 maupun XI MIPA 2 tidak ada peserta didik yang memperoleh nilai $\geq 75$ yang merupakan nilai KKM yang digunakan sekolah. Nilai tertinggi yang diperoleh dari kedua kelas yaitu 67.

Menyikapi permasalahan mengenai rendahnya kemampuan berpikir kritis peserta didik maka perlu adanya perbaikan proses pembelajaran. Salah satu upaya untuk melatih kemampuan berpikir kritis peserta didik yaitu dengan memilih suatu model pembelajaran yang lebih menekankan kepada keaktifan peserta didik dan menekankan pada kemampuan berpikir kritis. Model pembelajaran Search, Find, and Construct Together (SFCT) merupakan model pembelajaran yang dikembangkan untuk meningkatkan daya pikir peserta didik melalui aktivitas dan interaksi belajar, yaitu kegiatan mencari (search), menemukan (find) konsep dari kegiatan pemecahan masalah yang diberikan oleh guru, kemudian konsep yang telah ditemukan dari hasil pemecahan masalah tersebut dibangun bersama (construct together) dalam kegiatan pembelajaran (Rohmaniyah, 2015: 23). Bruner (dalam Rohmaniyah, 2015: 44), menganggap bahwa belajar dengan penemuan sesuai dengan pencarian pengetahuan secara aktif oleh manusia sehingga dapat memberikan hasil yang paling baik. Salah satu kelebihan dari belajar dengan penemuan yaitu pengetahuan akan bertahan lama dalam ingatan atau lebih mudah diingat bila dibandingkan dengan pengetahuan yang dipelajari dengan cara lain dan hasil belajar dengan penemuan mempunyai efek transfer yang lebih baik dari pada hasil belajar dengan metode lain. 
Model pembelajaran konvensional diartikan sebagai model pembelajaran yang biasa digunakan oleh guru di sekolah dimana penelitian ini dilaksanakan. Pembelajaran yang biasa dilaksanakan oleh guru di SMA Negeri 2 Malang adalah pembelajaran dengan metode ekspositori sehingga model pembelajaran konvensional yang dimaksud dalam penelitian ini adalah pembelajaran matematika dengan metode ekspositori. Pembelajaran ekspositori merupakan kegiatan mengajar yang berpusat pada guru. Guru aktif memberikan penjelasan terperinci tentang bahan pengajaran. Tujuan utama pembelajaran ekspositori adalah memindahkan pengetahuan, keterampilan dan nilai-nilai pada peserta didik (Dimyati, 2002). Pada pembelajaran ekspositori guru lebih aktif terhadap pembelajaran dimana guru menyampaikan materi secara langsung kepada peserta didik.

Tujuan penelitian ini yang pertama adalah untuk mengetahui perbedaan kemampuan berpikir kritis antara peserta didik kelas eksperimen yang diajar menggunakan model pembelajaran SFCT dan kelas kontrol yang diajar menggunakan model pembelajaran konvensional pada materi matriks kelas XI SMA Negeri 2 Malang, dan yang kedua untuk mendeskripsikan kemampuan berpikir kritis antara peserta didik yang diajar menggunakan model pembelajaran SFCT dan peserta didik yang diajar menggunakan model pembelajaran konvensional pada materi matriks kelas XI SMA Negeri 2 Malang.

\section{METODE}

Pendekatan yang digunakan dalam penelitian ini yaitu pendekatan dengan metode campuran (mixed methods) dengan desain sequential explanatory. Dimana peneliti menggunakan metode kuantitatif pada tahap pertama dan metode kualitatif pada tahap kedua, karena dalam penelitian ini bertujuan untuk mengetahui kemampuan berpikir kritis peserta didik melalui penerapan model pembelajaran SFCT dan model pembelajaran konvensional serta mendeskripsikan analisis kemampuan berpikir peserta didik melalui penerapan model pembelajaran SFCT dan konvensional.

Lokasi yang digunakan dalam penelitian ini yaitu SMA Negeri 2 Malang, populasi dalam penelitian ini yaitu seluruh peserta didik kelas SMA Negeri 2 Malang, sampel penelitian yang digunakan dalam penelitian adalah kelas XI MIPA 1 sebagai kelas eksperimen dan kelas XI MIPA 2 sebagai kelas kontrol.

\section{Metode Penelitian Kuantitatif}

Penelitian kuantitaif ini menggunakan jenis penelitian eksperimen dengan desain penelitian menggunakan Pretest-Posttest Control Group Design. Sampel penelitian ini menggunakan dua kelas, yaitu satu kelas eksperimen yang diajarkan menggunakan model pembelajaran SFCT dan satu kelas kontrol yang diajarkan dengan pembelajaran konvensional. Teknik pengumpulan data kuantitatif dilakukan dengan metode tes. Metode tes tersebut digunakan untuk memperoleh data tentang kemampuan berpikir kritis peserta didik dalam pembelajaran matematika sebelum dan sesudah dikenai perlakuan. Tes yang diberikan adalah soal pre-test dan post-test yang berupa soal uraian. Sebelum dimulai pembelajaran, kelas eksperimen dan kelas kontrol diberi tes awal atau pretest untuk mengukur kondisi awal kemampuan berpikir kritis peserta didik. Selanjutnya kelas eksperimen diberi perlakuan pembelajaran dengan model pembelajaran Search, Find, and Construct Together (SFCT) dan kelas kontrol tidak diberi perlakuan atau dengan menggunakan model pembelajaran konvensional. Setelah selesai pembelajaran, kelas eksperimen dan kelas kontrol diberi tes akhir atau post-test untuk mengukur kondisi akhir kemampuan berpikir kritis peserta didik. Instrumen yang digunakan dalam penelitian ini berupa soal tes kemampuan berpikir kritis peserta didik berupa soal uraian dan terdiri dari 4 item yang memuat indikator kemampuan berpikir kritis. Soal tes telah diuji validitas dan reliabilitas. Analisis data yang digunakan yaitu uji t, dengan uji prasyarat uji normalitas dan homogenitas menggunakan software SPSS 20. 


\section{Metode Penelitian Kualitatif}

Pada penelitian ini jenis penelitian kualitatif yang digunakan adalah deskriptif kualitatif, yaitu suatu prosedur penelitian yang menggunakan data deskriptif berupa kata-kata tertulis atau lisan dari orang-orang dan pelaku yang dapat diamati. Subjek penelitian kualitatif ini dipilih berdasarkan hasil tes kemampuan berpikir kritis dan dikelompokkan menjadi tiga kriteria yaitu peserta didik dengan kemampuan berpikir kritis tinggi, sedang, dan rendah. Sedangkan yang menjadi objek penelitian yaitu penggunaan model pembelajaran Search, SFCT dan model pembelajaran konvensional dalam melatih kemampuan berpikir kritis peserta didik. Teknik pengumpulan data yang digunakan yaitu observasi, wawancara, dan catatan lapangan yang telah di validasi oleh ahli yaitu Bapak Isbadar Nursit, M.Pd dan praktisi yaitu Ibu Farida Agustiningsih, S.Si. Teknik analisis data yang digunakan dilapangan menggunakan model Miles dan Huberman yaitu yaitu data reduction, data display, dan conclusion drawing/verification. Uji keabsahan data yang digunakan yaitu metode triangulasi.

\section{Analisis Data Kuantitatif dan Kualitatif}

Setelah uraian analisis data secara kuantitatif dan kualitatif diatas, maka analisis data hasil antara penelitian kuantitatif pada tahap pertama dan kualitatif pada tahap kedua tersebut dianalisis dengan metode sequential explanatory, yaitu analisis metode kuantitatif pada tahap pertama yaitu (1) Tes: data yang diperoleh dari hasil pre-test dan post-test kemampuan berpkir kritis menggunakan model pembelajaran SFCT dan konvensional; (2) Analisis statistik: mencari perbedaan kemampuan berpikir kritis peserta didik yang menggunakan model pembelajaran SFCT dan model pembelajaran konvensional dengan uji-t, selanjutnya analisis metode kualitatif pada tahap kedua yaitu: (1) Observasi, wawancara, dan catatan lapangan: data yang diperoleh dari informan dan pengamatan dalam proses pembelajaran menggunakan model pembelajaran SFCT dan model pembelajaran konvensional; (2) Reduksi data: memilih data yang penting, membuat kategori, dan membuang yang tidak diperlukan; (3) menyajikan data kuantitatif dan kualitatif ke dalam pola, tabel atau grafik; (4) Konklusi/verifikasi: penarikan kesimpulan dan verifikasi dari penelitian.

Menurut Sugiyono (2015: 416) langkah-langkah penelitian metode campuran menggunakan desain sequential explanatory yaitu pada tahap pertama menggunakan metode kuantitatif: menentukkan masalah/potensi dan membuat rumusan masalah, melakukan kajian teori dan merumuskan hipotesis, mengumpulkan dan analisis data untuk menguji hipotesis, dan selanjutnya dapat dibuat kesimpulan berdasarkan hasil pengujian hipotesis; pada tahap kedua menggunakan metode kualitatif: metode kualitatif digunakan untuk membuktikan, memperkuat, memperdalam, memperluas, memperlemah atau menggugurkan data kualitatif penggunaan metode kualitatif berangkat dari hasil penelitian kuantitatif yaitu (1) penentuan sumber data; (2) pengumpulan dan analisis data kualitatif; (3) analisis data kuantitatif dan kualitatif; (4) kesimpulan hasil penelitian.

\section{HASIL}

Dalam penelitian ini peneliti menggunakan tes berupa tes uraian yang sudah diuji validitas dan reliabilitasnya untuk digunakan sebagai instrumen pengumpulan data kuantitatif. Sebelum tes tersebut digunakan terlebih dahulu dilakukan validasi konstruksi dan validasi ini, untuk memperoleh soal tes yang valid. Validasi konstruksi dilakukan oleh ahli yaitu dosen pendidikan matematika UNISMA dan praktisi yaitu guru matematika SMA Negeri 2 Malang. Sedangkan pengumpulan data kualitatif menggunakan hasil observasi, wawancara, dan catatan lapangan.

Berdasarkan hasil validasi yang dilakukan olehvalidator, terdapat 4 butir soal yang akan diuji namun ada satu soal yag perlu sedikit diperbaiki dan berdasarkan hasil validasi tersebut diperoleh bahwa soal pre-test dan post-test kemampuan berpikir kritis sudah valid dan dapat digunakan dengan sedikit revisi. Dari empat butir soal tersebut mengukur 4 indikator berpikir kritis 
yang digunakan dalam penelitian ini yaitu elementary clarification (memberikan penjelasan sederhana), strategies and tactics (strategi dan taktik), advanced clerivication (membuat penjelasan lebih lanjut), dan inference (menyimpulkan).

\section{Hasil Analisis Kuantitatif}

Berdasarkan analisis data kuantitatif kemampuan berpikir kritis peserta didik kelas eksperimen yang diajar menggunakan model SFCT dan kelas kontrol yang diajar menggunakan model konvensional sebagai berikut.

Tabel 5 Nilai Mean dan Standart Deviation

\begin{tabular}{|c|c|c|c|c|c|c|}
\hline \multirow{2}{*}{\multicolumn{2}{|c|}{ Model Pembelajaran }} & \multicolumn{2}{|c|}{ Mean } & \multicolumn{2}{|c|}{ Standar Deviasi } & \multirow{2}{*}{$\begin{array}{c}\text { Jumlah Peserta } \\
\text { Didik } \\
\end{array}$} \\
\hline & & Pre-test & Post-test & Pre-test & Post-test & \\
\hline & SFCT & 46,96 & 79,30 & 11,569 & 14,451 & 33 \\
\hline & Konvensional & 46,21 & 70,18 & 12,002 & 12,820 & 33 \\
\hline & Jumlah & 93,17 & 149,48 & 23,571 & 27,271 & 66 \\
\hline & Rata-rata & 46,58 & 74,74 & 11,785 & 13,635 & - \\
\hline \multicolumn{7}{|c|}{ Tabel 6 Hasil Analisis Tes Berpikir Kritis } \\
\hline \multirow[b]{2}{*}{ No } & \multirow{2}{*}{\multicolumn{4}{|c|}{ Hasil Analisis Tes }} & \multicolumn{2}{|r|}{ Jumlah } \\
\hline & & & & & $\begin{array}{c}\text { Kelas } \\
\text { Eksperimen }\end{array}$ & Kelas Kontrol \\
\hline 1. & Rata-rata & & & & 79,30 & 70,18 \\
\hline 2. & Nilai tertinggi & & & & 100 & 92 \\
\hline 3. & Nilai terendah & & & & 42 & 42 \\
\hline 4. & Jumlah peserta $\mathrm{c}$ & dik yang tu & & & 25 & 16 \\
\hline 5. & Jumlah siswa pe & erta didik y & ig belum tu & & 8 & 17 \\
\hline 6. & Presentase peser & a didik yang & untas & & $75,76 \%$ & $48,48 \%$ \\
\hline 7. & Presentase peser & a didik yans & elum tunt & & $24,24 \%$ & $51,52 \%$ \\
\hline
\end{tabular}

Dari Tabel 6 dapat diketahui bahwa peserta didik kelas eksperimen memperoleh nilai $\geq 75$ (tuntas) berjumlah 25 orang atau mencapai 75,76\%, yang $<75$ (tidak tuntas) berjumlah 8 orang atau mencapai $24,25 \%$. Sedangkan peserta didik kelas kontrol memperoleh nilai $\geq 75$ (tuntas) berjumlah 16 orang atau mencapai $48,48 \%$, yang $<75$ (tidak tuntas) berjumlah 17 orang atau mencapai 51,52 $\%$.

Tabel 7 Data Kemampuan Berpikir Kritis Tiap Indikator Kelas Sampel

\begin{tabular}{lcc}
\hline Indikator Kemampuan Berpikir Kritis & \multicolumn{2}{c}{ Persentase Ketercapaian } \\
\cline { 2 - 3 } & Kelas Eksperimen & Kelas Kontrol \\
\hline $\begin{array}{l}\text { Elementary clarification (memberikan } \\
\text { penjelasan sederhana) }\end{array}$ & $66,67 \%$ & $63,64 \%$ \\
\hline Strategies and tactics (strategi dan taktik) & $81,82 \%$ & $76,77 \%$ \\
\hline $\begin{array}{l}\text { Advanced clerivication (membuat penjelasan } \\
\text { lebih lanjut) }\end{array}$ & $80,81 \%$ & $50,51 \%$ \\
\hline Inference (menyimpulkan) & & \\
\hline Rata-rata & $87,88 \%$ & $86,87 \%$ \\
\hline
\end{tabular}

Berdasarkan Tabel 7, maka dapat disimpulkan bahwa terdapat perbedaan kemampuan berpikir kritis peserta didik antara kelas eksperimen yang diajar menggunakan model pembelajaran SFCT dan kelas kontrol yang diajar menggunakan model pembelajaran konvensional.

\section{Hasil Analisis Kualitatif}

Setelah nilai post-test diketahui maka diperoleh subjek wawancara yang berjumlah delapan belas peserta didik. Delapan belas peserta didik tersebut terdiri dari tiga peserta didik kelompok tinggi, tiga peserta didik kelompok sedang, dan tiga peserta didik kelompok rendah baik 
pada kelas eksperimen maupun kelas kontrol. Klasifikasi penilaian tersebut berdasarkan klasifikasi penilaian yang digunakan sekolah yaitu berdasarkan PAN (Pacuan Aturan Normal). Klasifikasi penilaian ditunjukkan pada Tabel 4.13 berikut.

Tabel 4.13 Klasifikasi Nilai Post-Test

\begin{tabular}{ccc}
\hline \multicolumn{2}{c}{ Rentang Nilai } & Klasifikasi \\
\cline { 1 - 2 } Kelas Eksperimen & Kelas Kontrol & \\
\hline $83-100$ & $76-92$ & Tinggi \\
\hline $67-82$ & $51-75$ & Sedang \\
\hline $0-66$ & $0-50$ & Rendah \\
\hline
\end{tabular}

Berdasarkan analisis data kualitatif yang diperoleh dari hasil wawancara dengan subjek kemampuan berpikir kritis tinggi, sedang, dan rendah baik dari kelas eksperimen maupun kelas kontrol diperoleh hasil yang ditunjukkan pada Tabel 8 berikut.

Tabel 8 Perbedaan Data Kualitatif Kelas Eksperimen dan Kelas Kontrol

\begin{tabular}{|c|c|c|}
\hline No. & Kelas Eksperimen & Kelas Kontrol \\
\hline 1 & $\begin{array}{l}\text { Sebesar } 77,78 \% \text { subjek menyatakan } \\
\text { senang mengikuti pembelajaran } \\
\text { menggunakan model pembelajaran SFCT }\end{array}$ & $\begin{array}{l}\text { Sebesar } 77,78 \% \text { subjek menyatakan tidak } \\
\text { senang mengikuti pembelajaran } \\
\text { menggunakan model pembelajaran } \\
\text { konvensional }\end{array}$ \\
\hline 2 & $\begin{array}{l}\text { Sebesar } 88,89 \% \text { subjek menyatakan } \\
\text { dengan menggunakan model pembelajaran } \\
\text { SFCT tugas-tugas yang diberikan lebih } \\
\text { memacu aktivitas mereka dalam } \\
\text { pembelajaran matematika }\end{array}$ & $\begin{array}{l}\text { Sebesar 77,78\% subjek menyatakan } \\
\text { dengan menggunakan model pembelajaran } \\
\text { konvensional tugas-tugas yang diberikan } \\
\text { tidak dapat memacu aktivitas mereka } \\
\text { dalam pembelajaran matematika }\end{array}$ \\
\hline 3 & $\begin{array}{l}\text { Sebesar } 80,56 \% \text { subjek sudah memenuhi } \\
\text { keempat indikator kemampuan berpikir } \\
\text { kritis }\end{array}$ & $\begin{array}{l}\text { Sebesar } 63,89 \% \text { subjek sudah memenuhi } \\
\text { keempat indikator kemampuan berpikir } \\
\text { kritis }\end{array}$ \\
\hline
\end{tabular}

Dari hasil perbedaan data kualitatif pada Tabel 8, maka dapat disimpulkan bahwa, (1) secara kualitatif model pembelajaran SFCT direspon dengan baik daripada model pembelajaran konvensional, (2) secara keseluruhan kemampuan berpikir kritis peserta didik kelas eksperimen lebih baik daripada kelas kontrol, (3) model pembelajaran SFCT lebih berpengaruh terhadap kemampuan berpikir kritis peserta didik dibandingkan model pembelajaran konvensional. Jadi hasil penelitian kualitatif juga menunjukkan adanya perbedaan kemampuan berpikir kritis antara kelas eksperimen dan kelas kontrol.

Hasil penelitian kualitatif tersebut mendukung, membuktikan dan melengkapi hasil penelitian kuantitatif yang juga menunjukkan adanya perbedaan signifikan dengan nilai sig sebesar 0,009 sehingga $H_{0}$ ditolak. Artinya terdapat perbedaan kemampuan berpikir kritis antara peserta didik kelas eksperimen yang diajar menggunakan model pembelajaran SFCT dan peserta didik kelas kontrol yang diajar menggunakan model konvensional.

\section{Hasil Analisis Data Kuantitatif dan Kualitatif}

Analisis dilakukan dengan cara membandingkan data kuantitatif dan data kualitatif tentang kemampuan berpikir kritis. Perbandingan data ditunjukkan pada Tabel 9 berikut.

Tabel 9 Data Kuantitatif dan Data Kualitatif Kemampuan Berpikir Kritis Antara Peserta Didik Kelas Eksperimen dan Kelas Kontrol

\begin{tabular}{|c|c|c|c|c|c|c|}
\hline \multirow[b]{2}{*}{ No. } & \multirow{2}{*}{$\begin{array}{c}\text { Indikator } \\
\text { Berpikir } \\
\text { Kritis }\end{array}$} & \multicolumn{2}{|c|}{ Data Kuantitatif } & \multicolumn{2}{|c|}{ Data Kualitatif } & \multirow[b]{2}{*}{ Kesimpulan } \\
\hline & & $\begin{array}{c}\text { Kelas } \\
\text { Eksperimen }\end{array}$ & $\begin{array}{c}\text { Kelas } \\
\text { Kontrol }\end{array}$ & $\begin{array}{c}\text { Kelas } \\
\text { Eksperimen }\end{array}$ & $\begin{array}{c}\text { Kelas } \\
\text { Kontrol }\end{array}$ & \\
\hline 1. & $\begin{array}{l}\text { Elementary } \\
\text { clarification } \\
\text { (memberikan }\end{array}$ & $66,67 \%$ & $63,64 \%$ & $\begin{array}{l}\text { Dapat } \\
\text { mengidentifik } \\
\text { asi masalah }\end{array}$ & $\begin{array}{l}\text { Dapat } \\
\text { mengidenti } \\
\text { fikasi }\end{array}$ & $\begin{array}{l}\text { Melengkapi, } \\
\text { membuktika } \\
\text { n dan }\end{array}$ \\
\hline
\end{tabular}




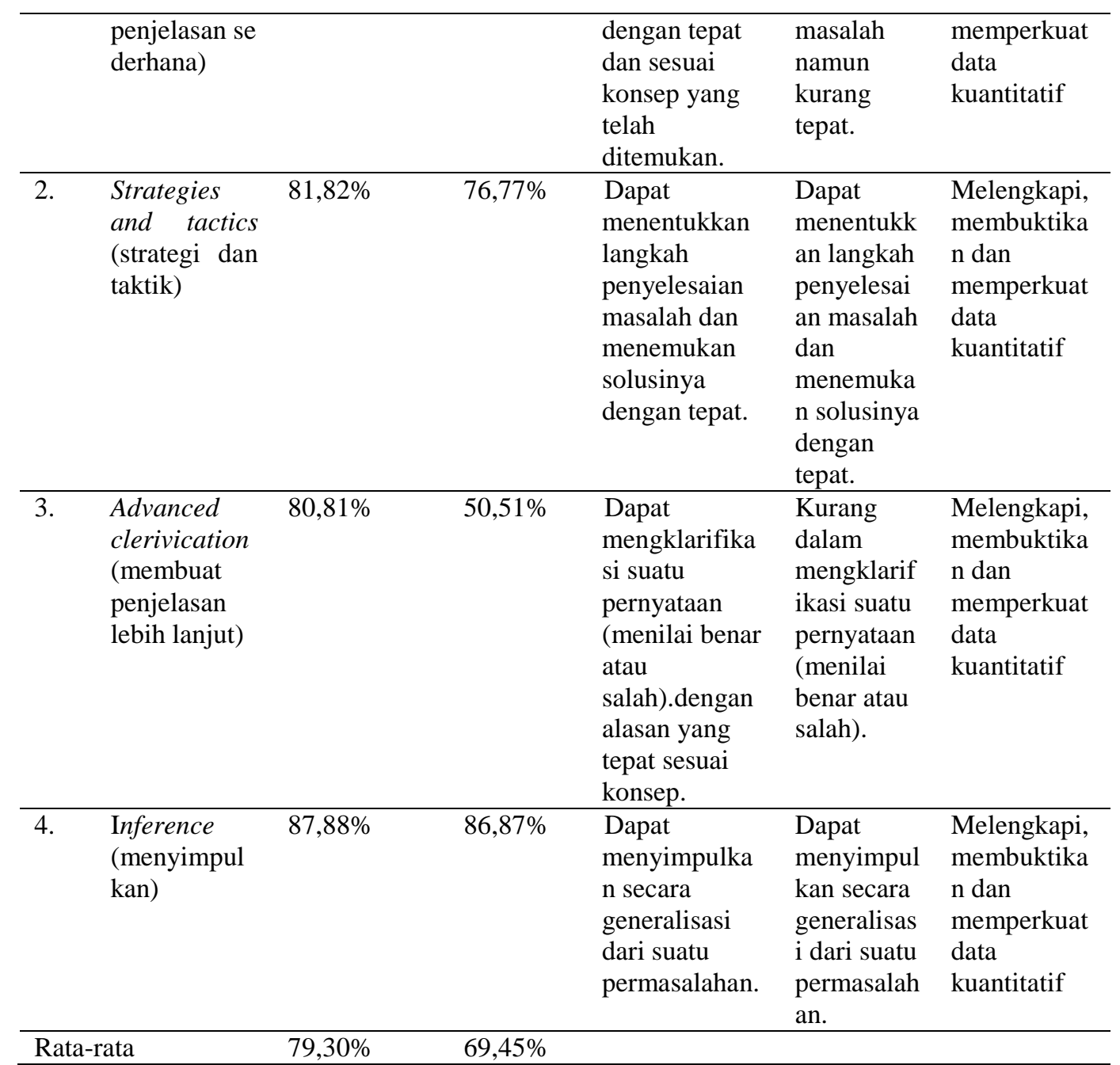

Berdasarkan analisis data yang ditunjukkan pada Tabel 9 tersebut terlihat bahwa, penelitian kualitatif yang dilakukan pada tahap kedua dapat menghasilkan data kualitatif yang membuktikan, melengkapi, dan memperkuat data kuantitatif kemampuan berpikir kritis peserta didik. Secara keseluruhan nilai kuantitatif kemampuan berpikir kritis peserta didik kelas eksperimen $=79,30 \%$ dan secara kualitatif, kemampuan berpikir kritis peserta didik juga dinyatakan baik. Sedangkan secara keseluruhan nilai kuantitatif kemampuan berpikir kritis peserta didik kelas kontrol $=69,45 \%$ dan secara kualitatif, kemampuan berpikir kritis peserta didik juga dinyatakan cukup baik. Jadi tidak terdapat perbedaan antara data kualitatif dan kuantitatif tentang kemampuan berpikir kritis peserta didik.

\section{PEMBAHASAN}

Berdasarkan hasil analisis data pre-test kemampuan berpikir kritis diperoleh bahwa kedua kelompok sampel berdistribusi normal, homogen dan tidak ada perbedaan antara kelas eksperimen dan kelas kontrol berarti sampel berasal dari keadaan atau kondisi yang sama. Hasil tes kemampuan berpikir kritis peserta didik diukur menggunakan hasil post-test. Berdasarkan Hasil pengujian hipotesis diperoleh bahwa $\mathrm{H}_{0}$ ditolak, artinya terdapat perbedaan kemampuan berpikir kritis yang signifikan antara peserta didik kelas eksperimen dan kelas kontrol.

Perbedaan kemampuan berpikir kritis peserta didik antara kelas kontrol dan kelas eksperimen dapat dilihat dari nilai post-test. Pada kelas eksperimen nilai tertinggi peserta didik sebesar 100 dan terendah 42 serta nilai rata-rata post-test sebesar 79,30. Sedangkan pada kelas kontrol nilai tertinggi peserta didik sebesar 92 dan terendah 42 serta nilai rata-rata post-test sebesar 
70,18. Berdasarkan hasil observasi dan catatan lapangan terlihat bahwa peserta didik kelas eksperimen lebih aktif dalam pembelajaran, serta berdasarkan hasil wawancara persentase peserta didik kelas eksperimen yang memenuhi keempat indikator berpikir kritis lebih tinggi dibandingkan peserta didik kelas eksperimen. Dari hasil tersebut maka dapat disimpulkan bahwa pembelajaran menggunakan model pembelajaran SFCT lebih efektif, ini sesuai dengan pendapat Bruner (dalam Rohmaniyah, 2015: 44), yang menganggap bahwa belajar dengan penemuan sesuai dengan pencarian pengetahuan secara aktif oleh manusia dan dengan sendirinya memberikan hasil yang paling baik.

Berdasarkan penelitian secara kualitatif ada perbedaan antara kelas eksperimen dan kelas kontrol sehingga hasil kualitatif dapat mendukung hasil penelitian kuantitatif, hal ini didukung oleh teori mixed method dengan desain sequential explanatory bahwa data kuantitatif pada tahap awal didukung oleh data kualitatif pada tahap akhir.

\section{SIMPULAN DAN SARAN}

Berdasarkan hasil penelitian yang dilaksanakan, diperoleh simpulan sebagai berikut:

(1) Berdasarkan hasil analisis data kuantitatif dengan uji hipotesis menggunakan software SPSS 20 diperoleh nilai Sig 2-tailed $=0,009$. Karena nilai $\operatorname{Sig}=0,009<0,025$ maka $H_{0}$ ditolak atau $H_{1}$ diterima. Hal ini berarti dapat disimpulkan bahwa terdapat perbedaan yang signifikan kemampuan berpikir kritis antara peserta didik yang memperoleh materi matriks menggunakan model pembelajaran SFCT dan peserta didik yang menggunakan model konvensional; (2) Berdasarkan analisis data kualitatif yang diperoleh dari wawancara dapat disimpulkan bahwa 77,78\% peserta didik merasa senang diajar dengan menggunakan model pembelajaran SFCT. Kemampuan berpikir kritis peserta didik yang diajar dengan menggunakan model SFCT termasuk dalam kategori baik. Sebanyak $80,56 \%$ peserta didik sudah memenuhi empat indikator berpikir kritis. Pada kelas kontrol terdapat $77,78 \%$ yang menyatakan tidak senang diajar dengan menggunakan model konvensional. Kemampuan berpikir kritis peserta didik yang diajar dengan menggunakan model konvensional dalam kategori cukup baik. Hanya 63,86\% peserta didik yang memenuhi empat indikator berpikir kritis.

Dari hasil penelitian ini diharapkan dapat memberikan sumbangan ide-ide dalam upaya meningkatkan kualitas pembelajaran matematika, khususnya dalam melatih kemampuan berpikir kritis peserta didik. Oleh karena itu, diberikan saran sebagai berikut: (1) Bagi guru: model pembelajaran Search, Find, and Construct Together (SFCT) membutuhkan waktu yang cukup lama. Untuk itu bagi guru yang hendak menggunakan model pembelajaran Search, Find, and Construct Together (SFCT) dalam pembelajaran di kelas diharapkan dapat mengatur waktu lebih baik lagi, mempersiapkan dan melaksanakan pembelajaran dengan seefektif mungkin agar pembelajaran dapat diselesaikan dengan baik dan tepat waktu, dan saat berdiskusi kelompok guru harus membimbing peserta didik agar konsep materi yang akan mereka temukan sesuai dengan tujuan pembelajaran; (2) Bagi peneliti selanjutnya: bagi peneliti selanjutnya yang akan mengadakan penelitian tentang model pembelajaran model Search, Find, and Construct Together (SFCT) terhadap kemampuan berpikir kritis, disarankan penelitian ini dapat dilengkapi dengan meneliti aspek yang belum terjangkau seperti meneliti kemampuan matematik lain, meneliti tentang peningkatan ataupun pengaruh, dan diharapkan untuk menggunakan pada materi yang lain serta pada jenjang pendidikan yang berbeda.

\section{DAFTAR RUJUKAN}

As'ari, A. R. (2016). Variasi Konstruk dalam Pembelajaran Matematika. Malang: Bintang Sejahtera.

Dimyati \& Mudjiono. (2002). Belajar dan Pembelajaran. Jakarta:Rineka Cipta. Heruman. (2012). Model Pembelajaran Matematika. Bandung: Rosda Karya. 
Hudojo, H. (2005). Pengembangan Kurikulum dan Pembelajaran Matematika. Malang: Universitas Negeri Malang UM Press.

Nurhalifah. (2014). Penerapan Model Pembelajaran AIR (Auditory, Intelelectually, Repetition) dengan Penilaian Portofolio untuk meningkatkan Kemampuan Penalaran Matematika Siswa Materi Segi Empat kelas VII-C MTs Al-Ma'arif 1 Singosari. Skripsi tidak diterbitkan. Malang. Program Studi Pendidikan Matematika. Universitas Islam Malang.

Rohmaniyah, L. (2015). Pengembangan Model Pembelajaran Matematika SFCT (Search, Find, and Construct Together) untuk SMA Kelas XI. Skripsi tidak diterbitkan. Malang. Program Studi Pendidikan Matematika. Universitas Islam Malang.

Sanjaya, W. (2009). Strategi Pembelajaran Berorientasi Standar Proses Pendidikan. Jakarta: Prenadamedia Group.

Sugiyono. (2015). Metode Penelitian Kombinasi (Mixed Methods). Bandung: Alfabeta.

Suwarma, D. M. (2009). Suatu Alternatif Pembelajaran Kemampuan Berpikir Kritis Matematika. Jakarta: Cakrawala Maha Karya.

Undang-Undang Republik Indonesia Nomor 20 Tahun 2003 tentang Sistem Pendidikan Nasional. (2003). Jakarta: Armas Duta Jaya.

Uno, H. B. (2014). Model Pembelajaran: Menciptakan Proses Belajar Mengajar yang Kreatif dan Efektif. Jakarta: Bumi Aksara. 